\title{
A preliminary molecular epidemiologic study using analysis of variable number of tandem repeats of Acinetobacter baumannii OXA-23 producing strains isolated from hospitals in Rio de Janeiro State, Brazil
}

Estudo epidemiológico molecular preliminar usando a análise de número variável de repetições em tandem (VNTR) de cepas de Acinetobacter baumannii produtoras de OXA-23 isoladas em hospitais no Rio de Janeiro, Brasil

Estudio epidemiológico molecular preliminar usando el análisis de número variable en tándem de repeticiones (VNTR) de cepas de Acinetobacter baumannii productoras de OXA-23 aisladas en hospitales de Rio de Janeiro, Brasil

Isabel Nogueira Carramachi

Laboratório de Transmissores de Leishmaniose, Setor de Entomologia Médica e Forense, Instituto Oswaldo Cruz, Fundação Oswaldo Cruz, Rio de Janeiro, Rio de Janeiro, Brasil

Karyne Rangel Carvalho

Departamento de Microbiologia, Laboratório de Saneantes, Instituto Nacional de Controle de Qualidade em Saúde, Fundação Oswaldo Cruz, Rio de Janeiro, Rio de Janeiro, Brasil
Jéssica Gonçalves Vieira da Cruz

Laboratório de Transmissores de Leishmaniose, Setor de Entomologia Médica e Forense, Instituto Oswaldo Cruz, Fundação Oswaldo Cruz, Rio de Janeiro, Rio de Janeiro, Brasil

\section{Viviane Zahner}

Laboratório de Transmissores de Leishmaniose, Setor de Entomologia Médica e Forense, Instituto Oswaldo Cruz, Fundação Oswaldo Cruz,

Rio de Janeiro, Rio de Janeiro, Brasil

\begin{abstract}
The Gram-negative multidrug-resistant (MDR) bacterium Acinetobacter baumannii constitutes a serious cause of nosocomial infections in Brazilian hospitals. A panel of 36 strains, belonging to five pre-determined pulsed-field gel electrophoresis (PFGE) genotypes from four different hospitals in the City of Rio de Janeiro, Rio de Janeiro State, Brazil, was submitted to simple agarose gel electrophoresis to determine the variation of nine variable number tandem repeats (VNTR) band profiles. Based on published data VNTR were classified in two categories, long (L) and short (S) repeats with different evolutionary implications. The results demonstrated the superior discrimination of VNTR over PFGE. The VNTR Abaum_3002 marker was the least discriminatory with only one allele, while VNTR10 and Abaum_2240 each presented four alleles. The use of a combination of the nine VNTR resulted in a refined genotyping tool that provides valuable epidemiological information.
\end{abstract}

Keywords: Acinetobacter baumannii; VNTR; Public Health; Epidemiology.

The Gram-negative bacterium, multidrug-resistant (MDR) Acinetobacter baumannii' constitutes a signficant cause of nosocomial infections in Brazilian hospitals. According to the MYSTIC Program Brazil ${ }^{2}$ it features considerably among the total number of nosocomial bacterial isolates recorded in intensive care units. Moreover, the carbapenemases OXA-23 and OXA-143 continue to be observed in Brazilian hospitals ${ }^{3}$. Recently Zarrilli et $\mathrm{al}^{4}$ reviewed the phenotypic and genotypic methods for typing of A. baumannii. In 1996, Dijkshoorn et $\mathrm{al}^{5}$ reported the development of a rapid and simple detection method, based on analysis of variable

\footnotetext{
Correspondence / Correspondência / Correspondencia:

Viviane Zahner

Instituto Oswaldo Cruz, Fundação Oswaldo Cruz

Laboratório de Transmissores de Leishmaniose

Setor de Entomologia Médica e Forense

Av. Brasil, 4365. Bairro: Manguinhos

CEP: 21045-900 Rio de Janeiro-Rio de Janeiro-Brazil

Phone\#: +55 (21) 2562-1953 / (21) 2562-1915

E-mail:vzahner@fiocruz.br
}

number tandem repeats (VNTR), for clonal types of important nosocomial bacteria, that could potentially overcome the limitations and reduce the financial burden associated with pulsed-field gel electrophoresis (PFGE) and multilocus sequence typing (MLST). PFGE has a limited level of discrimination and is time consuming while MLST, although it is a portable technique, is a costly being restricted primarily to research laboratories ${ }^{6}$. VNTR have been found in the genomes of several bacteria including Staphylococcus aureus, Bacillus anthracis, Bacillus cereus and Neisseria $7,8,9,10,11$. Turton et $\mathrm{al}^{12}$ and Pourcel et $\mathrm{al}^{6}$ suggested the use of VNTR as a complement or even for substitution of the other methodologies. VNTR is a technique based on the PCR detection of specific repetitive sequence(s) active in different individuals, which results in an electrophoretic fingerprint. Multiple-locus VNTR analysis, also known as MLVA, presents the polymorphism among different tandemly repeated DNA sequences ${ }^{12}$. The division of VNTR markers into two groups is made according to their size and rate of evolution. Thus, Short repeats (S-repeats) 
are 6 to $9 \mathrm{bp}$ in length and appear to have a high rate of evolution, while Long repeats (L-repeats) are 26 to 99 $\mathrm{bp}$ in length and show a slower rate of evolution' ${ }^{6}$. This rationale was proposed to aid in phylogenetic studies, outbreak investigations and epidemiological surveillance ${ }^{6}$.

The occurrence of different PFGE types among OXA-23 producing $A$. baumannii in different hospitals in Rio de Janeiro State, Brazil, was reported in 2011, and more recently Carvalho ${ }^{13}$ studied some phenotypic characteristics such as, adherence to epithelial cells and biofilm formation in the same set of strains used in the present study. In addition, the strains were subjected to PCR and phenotypic detection of carbapenemases genes and characterization by MLST for population studies ${ }^{3}$. In light of the existing classification, we decided to investigate the potential utility of VNTR analysis using a small, but representative, panel of 36 strains of this collection of OXA-23-producing $A$. baumannii clinical isolates which were recovered from four different hospitals in Rio de Janeiro between January 2006 and September 2007 and that represented five PFGE types ${ }^{3,14}$. The 36 strains belong to the five previously defined PFGE genotypes (A, B, C, D and E) and $S$ (non-producing OXA-23) (Table 1) ${ }^{3}$. The VNTR profile (string numbers) was obtained by simple agarose gel electrophoresis of PCR amplicons according to previously described methodology 6 .

Table 1 - Characteristics of A. baumannii used in this study and the genetic diversity of PFGE group and MLVA profile

\begin{tabular}{|c|c|c|c|c|c|c|c|c|c|c|c|c|c|c|}
\hline Strain & $\begin{array}{l}\text { PFGE } \\
\text { group* }\end{array}$ & Sex & Source & Year & Origin & $\begin{array}{c}\mathrm{Ab} \\
2240^{+}\end{array}$ & $\begin{array}{c}\mathrm{Ab} \\
3002^{+}\end{array}$ & $\begin{array}{c}\mathrm{Ab} \\
1988^{+}\end{array}$ & $\begin{array}{c}\text { A } \\
3530^{+} \\
\end{array}$ & $\begin{array}{c}\mathrm{Ab} \\
3468^{+}\end{array}$ & $\begin{array}{c}\mathrm{Ab} \\
0826^{+}\end{array}$ & $\begin{array}{c}\mathrm{Ab} \\
0845^{+}\end{array}$ & VNTR If & VNTR 10‡ \\
\hline 15 & A & $F$ & Blood & 2006 & $\mathrm{Hl}$ & 2 & 1 & 1 & 2 & 3 & 2 & 1 & 2 & 2 \\
\hline 56 & A & $M$ & Liquor & 2006 & $\mathrm{H} 3$ & 4 & 1 & 1 & 2 & 1 & 2 & 1 & 3 & 2 \\
\hline 65 & A & $F$ & Liquor & 2006 & $\mathrm{H} 3$ & 3 & 1 & 1 & 2 & 2 & 1 & 1 & 2 & 2 \\
\hline 130 & $A$ & $M$ & WS & 2007 & $\mathrm{Hl}$ & 2 & 1 & 1 & 2 & 3 & 3 & 1 & 3 & 2 \\
\hline 167 & A & $F$ & TS & 2007 & $\mathrm{Hl}$ & 2 & 1 & 1 & 2 & 3 & 3 & 1 & 2 & - \\
\hline 175 & A & $F$ & BAL & 2007 & $\mathrm{Hl}$ & 2 & 1 & 1 & 2 & 3 & 3 & 1 & 2 & 2 \\
\hline 261 & A & $F$ & Catheter & 2007 & $\mathrm{H} 3$ & 2 & 1 & 1 & 2 & 3 & 2 & 1 & 3 & 2 \\
\hline 305 & A & $F$ & Blood & 2007 & $\mathrm{HI}$ & - & 1 & 1 & 2 & 1 & 2 & 1 & $1 / 3$ & 2 \\
\hline 317 & A & $M$ & Catheter & 2007 & $\mathrm{H} 4$ & 2 & 1 & 1 & 2 & 1 & 3 & 1 & 3 & 2 \\
\hline 325 & A & $M$ & Catheter & 2007 & $\mathrm{Hl}$ & 2 & 1 & 1 & 2 & 3 & 1 & 1 & 3 & - \\
\hline 350 & A & $M$ & Blood & 2007 & $\mathrm{H} 4$ & - & 1 & - & 2 & 1 & 2 & 1 & 3 & 2 \\
\hline 379 & A & $M$ & TS & 2007 & $\mathrm{H} 2$ & 2 & 1 & 1 & 2 & 2 & 1 & 1 & 3 & 2 \\
\hline 380 & A & $F$ & Sputum & 2007 & $\mathrm{H} 2$ & 2 & 1 & 1 & 2 & 2 & 3 & 1 & 3 & 2 \\
\hline 382 & A & $M$ & BAL & 2007 & $\mathrm{H} 2$ & 2 & 1 & 1 & 2 & 2 & 3 & 1 & 3 & 2 \\
\hline 384 & A & $M$ & Blood & 2007 & $\mathrm{H} 2$ & 2 & 1 & 1 & 2 & 1 & 3 & 1 & 3 & 1 \\
\hline 401 & A & $M$ & C & 2007 & $\mathrm{H} 2$ & 2 & 1 & 1 & 2 & 2 & 3 & 1 & 3 & 2 \\
\hline 405 & A & $F$ & Liquor & 2007 & $\mathrm{HI}$ & 2 & 1 & 1 & 2 & 1 & 3 & 1 & 3 & 2 \\
\hline 436 & A & $M$ & TS & 2007 & $\mathrm{H} 4$ & - & 1 & 1 & - & 3 & 3 & 1 & 3 & 1 \\
\hline 501 & A & $F$ & TS & 2007 & $\mathrm{H} 4$ & 2 & 1 & 1 & 2 & 2 & 3 & 1 & 3 & 2 \\
\hline 295 & B & $F$ & TS & 2007 & $\mathrm{H} 4$ & 1 & - & 2 & 2 & 1 & 3 & 1 & - & - \\
\hline 356 & B & $M$ & BAL & 2007 & $\mathrm{H} 3$ & 3 & 1 & 2 & 2 & 1 & 2 & 1 & 1 & 3 \\
\hline 375 & B & $M$ & Blood & 2007 & $\mathrm{H} 2$ & 1 & 1 & 2 & 2 & 1 & 2 & 1 & 1 & 4 \\
\hline 386 & B & $M$ & TS & 2006 & $\mathrm{H} 2$ & 3 & 1 & 2 & 2 & 1 & 2 & 2 & 1 & 3 \\
\hline 387 & B & $M$ & BAL & 2007 & $\mathrm{Hl}$ & 3 & 1 & 2 & 2 & 1 & 2 & 2 & 1 & $2 / 3$ \\
\hline 394 & B & $F$ & TS & 2006 & $\mathrm{H} 2$ & 3 & 1 & 2 & 2 & 1 & 2 & 2 & 1 & 4 \\
\hline 396 & B & $F$ & TS & 2006 & $\mathrm{H} 2$ & 3 & 1 & 2 & 2 & 1 & 2 & 2 & 1 & 3 \\
\hline 403 & B & $M$ & AS & 2007 & $\mathrm{Hl}$ & 3 & 1 & 2 & 1 & 3 & 1 & 2 & 1 & 1 \\
\hline 470 & B & $\mathrm{F}$ & Blood & 2007 & H3 & 3 & 1 & 2 & 1 & 3 & 2 & 1 & - & 1 \\
\hline 473 & B & $M$ & BAL & 2007 & $\mathrm{H} 3$ & 3 & 1 & 2 & 1 & 3 & 3 & 1 & - & 1 \\
\hline 480 & B & $M$ & TS & 2007 & $\mathrm{H} 3$ & 3 & 1 & 2 & 1 & 3 & 3 & 1 & - & 1 \\
\hline 535 & C & $M$ & WS & 2007 & $\mathrm{HI}$ & - & 1 & 2 & 2 & 1 & 2 & 1 & 1 & 3 \\
\hline 539 & C & $M$ & BAL & 2007 & $\mathrm{H} 3$ & 1 & 1 & 2 & 2 & 1 & 2 & 1 & 1 & $2 / 3$ \\
\hline 542 & $C$ & $M$ & Blood & 2007 & $\mathrm{H} 3$ & 1 & 1 & 2 & 2 & 2 & 3 & 1 & - & 3 \\
\hline 71 & D & $M$ & An Swab & 2007 & $\mathrm{H} 4$ & 3 & 1 & 1 & 2 & 3 & 2 & 1 & 2 & 2 \\
\hline 508 & $E$ & $M$ & Blood & 2007 & $\mathrm{Hl}$ & 2 & 1 & - & - & 2 & 3 & 2 & 3 & 2 \\
\hline 549 & S & $\mathrm{F}$ & Urine & 2007 & H3 & 1 & - & 2 & - & 1 & - & 1 & 1 & 1 \\
\hline
\end{tabular}

WS: wound secretion; TS: traqueal secretion; BAL: bronchoalveolar lavage; An swab: anal swab; AS: abdominal secretion; C: culture; ${ }^{*}$ Grosso et al ${ }^{3}$; tPourcel et $\mathrm{al}^{6}$; :Turton et $\mathrm{al}^{12}$; (-) null allele. 
As reported by Grosso et $\mathrm{al}^{3}$, strains from PFGE type A, B, C and D were classified as ST131, ST132, ST133 and ST134 in accordance with the MLSTOD scheme (associated with the Oxford Database) and ST79, ST15 and two new allelic profiles within the MLST-IP scheme (developed by the Institute Pasteur). The genotypes $\mathrm{E}$ and $\mathrm{S}$ were not submitted to multilocus sequence typing (MLST) schemes.

In the present study we included nine VNTR primer pairs; Abaum_2240, Abaum_3002, Abaum_1988, Abaum_3530 (long-repeats), Abaum_3468, Abaum_0845, Abaum_0826, VNTR1 and VNTR10 (short-repeats). The amplification conditions used were as described by Pourcel et al ${ }^{6}$. The PCR amplicons were submitted to electrophoresis in 3.2\% (S-repeats) and $2 \%$ (L-repeats) agarose gels. Following electrophoresis the molecular weight (MW) of each band was estimated using the Lablmage 1D gel analysis program (Loccus Biotecnologia, Brazil). In the present study a dendrogram based on VNTR profiles (Figure 1) was created and comparison of the banding patterns was accomplished employing the unweighted pair-group method with arithmetic averages using the Dice similarity coefficient. Computer-assisted analysis was performed using BioNumerics v.4.0 (Applied Maths, Sint-Martens-Latem, Belgium).

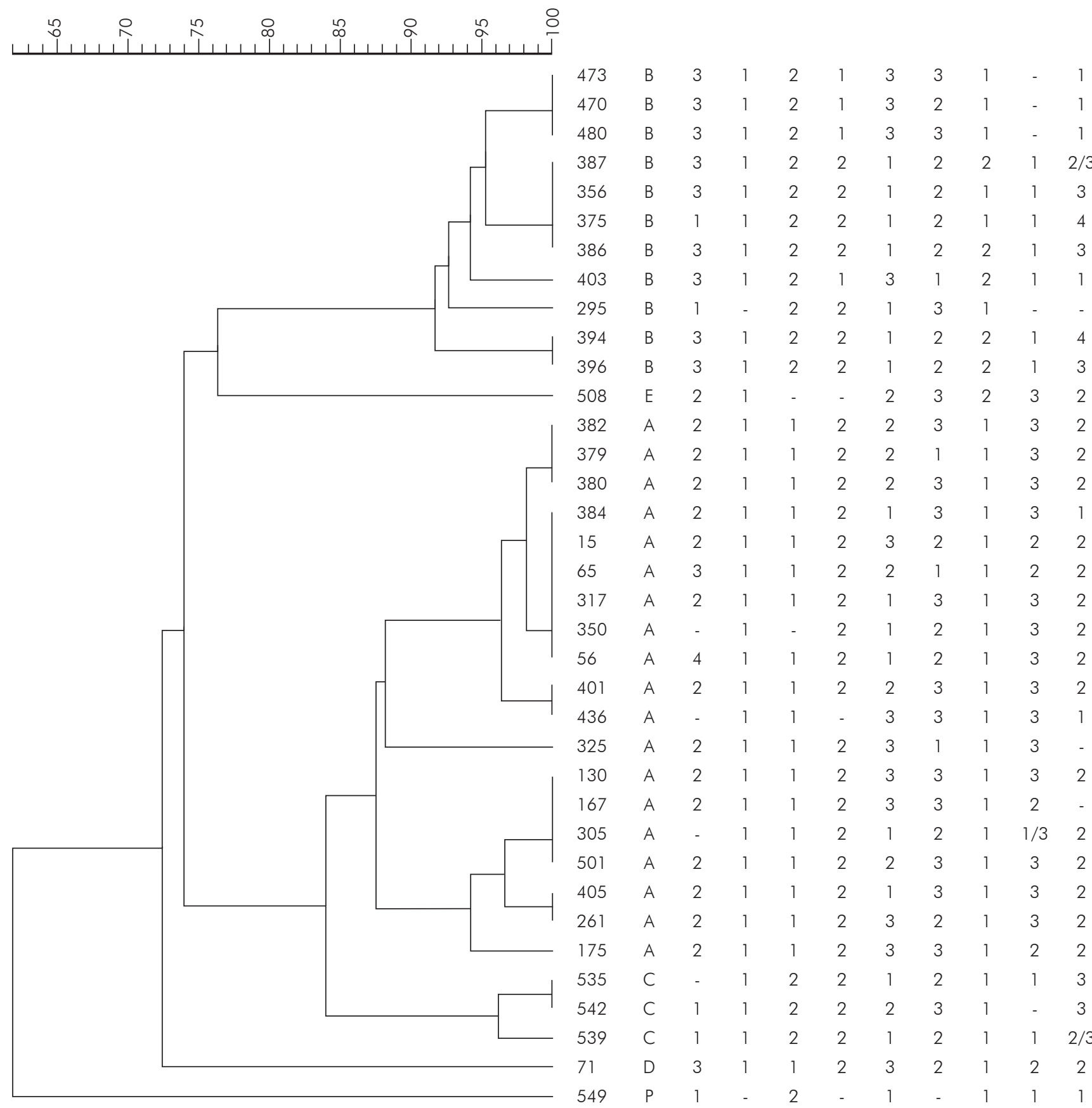

Figure 1 - VNTR profile: fingerprint concordance between MLVA-9 and PFGE typing. Dendrogram resulting from computer analysis of the PFGE profiles of A. baumannii isolated from four hospitals. The order of the profile (string number) of each VNTR is the same as in table 1 
Table 1 shows the VNTR alleles for each VNTR maker used in the study. The analysis of the 36 A. baumannii strains, detected 30 different VNTR profiles, each represented by string of numbers (Figure 1). The superior discrimination of VNTR relative to PFGE is clearly demonstrated in figure 1 where strains belonging to the same PFGE type presented variation in VNTR, with the exception of the strains LGB380, LGB382, LGB401, and LGB501 (genotype A), LGB317-LGB405 (genotype A), LGB386-LGB396 (genotype B) and LGB473-LGB480 (genotype B). As a specific example, the strains LGB130 and LGB305, both classified as PFGE type $A$ isolated in the same year from the same hospital at the same time, demonstrated differences in four VNTR (VNTR1, Abaum_3468, Abaum_0826 and Abaum_2240).

Top et $\mathrm{al}^{15}$ studying Enterococccus faecium demonstrated the discriminatory power of six VNTR-MLVA. More recently strains of $A$. baumannii, producers of $\mathrm{CHDL}$ belonging to ICL-II, were typed by MLVA-8 ${ }^{16}$. In addition, Hauck et al ${ }^{17}$ utilized an automated VNTR protocol in the investigation of A. calcoaceticus-A. baumannii complex strains from different hospitals. Moreover, Hu et $\mathrm{al}^{18}$ compared a VNTR based analysis with PFGE typing of A. baumannii in China and observed a remarkable congruence between MLVA-7 and PFGE-based strain clustering.

Taken as a whole our results are in congruence with data presented in the literature and support the use of VNTR analysis for discrimination of isolates of $A$. baumannii. According to table 1 it can be inferred that the similarity of MLVA is greater within PFGE profiles than between them. As such the use of VNTR does not undermine to PFGE data, but it does show a greater power for detecting genetic variation in clonal groups than can be achieved by PFGE. It was noted that the marker Abaum 1988, except in the case of strain LGB350 (which seems to have a null allele for this VNTR), was conserved among strains of PFGE type A. Nevertheless, more strains should be analyzed in order to confirm if these loci could be employed as a molecular marker of Brazilian PFGE type A. Interestingly, no genetic variation was observed among our samples using the VNTR Abaum 3002, which is in contrast with data reported by Pourcel et $a^{6}$ which showed that this marker generated three numbers of alleles or types.

It was suggested previously that determination of the number of repeats in VNTR1 and VNTRIO could be valuable in cross-infection studies, with VNTR1 providing the greatest level of discrimination ${ }^{12}$, at least among the isolates of OXA-23 clone 1 that were included in that study. It is clear that the discriminatory power of this technique depends on the choice of locus. In this context, our data based on the number of alleles showed that VNTR10 was the most polymorphic among the $\mathrm{S}$-repeats while
Abaum 2240 were the most polymorphic among the L-repeats, both produced four alleles each (bands) among our strains. Moreover, within the same PFGE group, the VNTR10 and Abaum 2240 markers revealed more differences, an observation which may prove useful in studies that need to be simple, faster and cheaper. In addition, strains with the same PFGE type from different hospitals but from the same hospital chain, e.g. strains LGB382 and LGB130 or strains LGB386 and LGB387 presented a single loci difference: Abaum 3468 and VNTR 10, respectively, S-repeat (Table 1), suggesting that the traffic of employees and material between hospitals may serve to promote dissemination of this bacterium. In this context, the analysis of a group of isolates from the same hospital and belonging to the same PFGE group showed higher rates of evolution in the S-repeat in comparison to L-repeat markers. Indeed, with the exception of Abaum_2240 the pattern of L-repeats was maintained among PFGE-types, while the pattern of $S$-repeats was highly polymorphic.

The dissemination of $A$. baumannii in Rio de Janeiro is reflected by the detection of the same VNTR genotype in different hospitals. This observation calls for improvements in the procedures for prevention of hospital infection and prudence in the use of carbapenems. Improved recognition and early detection of potentially epidemic isolates that show a propensity to emerge in hospital wards can be determined by MLST, and also, based on our data, by VNTR. In light of these data we contend that VNTR should be considered as an important tool for infection control.

Although a VNTR data bank (http://mlva.u-psud.fr/) 9 exists, we did not use this resource since our intention was to facilitate the routine of laboratories which receive samples from hospitals for screening. In conclusion, our results corroborate the impressive discriminatory power of VNTR, as reported by numerous authors and importantly, provide the first report of the applicability of this technique in Brazil. In light of the fact that both MLST and PFGE are technically demanding, expensive and time consuming, the use of VNTR, specifically VNTR10 (due the fact of being a short repeat marker) may be a candidate for further studies on the characterization of strains that belong to an outbreak and to the same PFGE genotype.

\section{ACKNOWLEDGMENTS}

To Dr. Douglas Mcintosh for English revision. To the Laboratório de Pesquisa em Infecção Hospitalar of the Instituto Oswaldo Cruz who provided the strains of Coleção de Culturas de Bactérias de Origem Hospitalar used in the present study.

\section{FINANCIAL SUPPORT}

Conselho Nacional de Desenvolvimento Científico e Tecnológico and Fundação de Amparo à Pesquisa do Estado do Rio de Janeiro. 
Estudo epidemiológico molecular preliminar usando a análise de número variável de repetições em tandem (VNTR) de cepas de Acinetobacter baumannii produtoras de OXA-23 isoladas em hospitais no Rio de Janeiro, Brasil

\section{RESUMO}

A bactéria Gram-negativa Acinetobacter baumannii multirresistente (AbMR) constitui uma séria causa de infecções nosocominais em hospitais brasileiros. Um painel de 36 cepas, pertencentes a cinco genótipos pré-determinados por eletroforese em gel de campo pulsado (PFGE) de quatro diferentes hospitais na Cidade do Rio de Janeiro, Estado do Rio de Janeiro, Brasil, foi submetido à eletroforese em gel de agarose simples para determinar a variação de nove perfis de número variável de repetições em tandem (VNTR). Com base em dados publicados, os VNTR foram classificados em duas categorias, longa (L) e curta $(C)$ repetições com diferentes implicações evolucionárias. Os resultados demonstraram a discriminação superior de VNTR sobre PFGE. O marcador VNTR Abaum_3002 era o menos discriminatório com apenas um alelo, enquanto VNTR10 e Abaum_2240, cada um, apresentaram quatro alelos. O uso da combinação de nove VNTR resultou em uma aperfeiçoada ferramenta de genotipagem que fornece relevantes informações epidemiológicas.

Palavras-chave: Acinetobacter baumannii; VNTR; Saúde Pública; Epidemiologia.

\section{Estudio epidemiológico molecular preliminar usando el análisis de número variable en tándem de repeticiones (VNTR) de cepas de Acinetobacter baumannii productoras de OXA-23 aisladas en hospitales de Rio de Janeiro, Brasil \\ RESUMEN}

La bacteria Gram negativa Acinetobacter baumannii multirresistente (AbMR) es una seria causa de infecciones nosocomiales en hospitales brasileños. Un panel de 36 cepas, pertenecientes a cinco genotipos predeterminados por electroforesis en gel de campo pulsado (PFGE) de cuatro diferentes hospitales en la Ciudad de Rio de Janeiro, Estado de Rio de Janeiro, Brasil, fue sometido a electroforesis en gel de agarosa simple para determinar la variación de nueve perfiles de número variable de repeticiones en tándem (VNTR). Con base en datos publicados, los VNTR fueron clasificados en dos categorías, larga (L) y corta (C) repeticiones con distintas implicaciones evolutivas. Los resultados demostraron la discriminación superior de VNTR sobre PFGE. El marcador VNTR Abaum_3002 era el menos discriminatorio con un solo alelo apenas, mientras que VNTR10 y Abaum_2240, cada uno, presentaron cuatro alelos. El uso de la combinación de nueve VNTR resultó en una herramienta de genotipado perfeccionada que suministra relevantes informaciones epidemiológicas.

Palabras clave: Acinetobacter baumannii; VNTR; Salud Pública; Epidemiología.

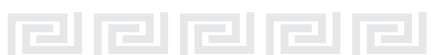

\section{REFERENCES}

1 Vila J, Pachón J. Acinetobacter baumannii resistant to everything: what should we do? Clin Microbiol Infect. $2011 \mathrm{Jul} ; 17(7): 955-6$.

2 Kiffer C, Hsiung A, Oplustiul C, Sampaio J, Sakayami $E$, Turner $P$, et al. Antimicrobial susceptibility of Gram-negative bacteria in Brazilian hospitals: the MYSTIC Program Brazil 2003. Braz J Infect Dis. 2005 Jun;9(3):216-24.

3 Grosso F, Carvalho KR, Quinteira S, Ramos A, Carvalho-Assef APD, Asensi MD, et al. OXA-23producing Acinetobacter baumannii: a new hotspot of diversity in Rio de Janeiro? J Antimicrob Chemother. 2011 Jan;66(1):62-5.

4 Zarrilli R, Pournaras S, Giannouli M, Tsakris A. Global evolution of multidrug-resistant Acinetobacter baumannii clonal lineages. Int J Antimicrob Agents. 2013 Jan;41(1):11-9.
5 Dijkshoorn L, Aucken H, Gerner-Smidt P, Janssen P, Kaufmann ME, Garaizar J, et al. Comparison of outbreak and nonoutbreak Acinetobacter baumannii strains by genotypic and phenotypic methods. J Clin Microbiol. 1996 Jun;34(6):1519-25.

6 Pourcel C, Minandri F, Hauck Y, D'Arezzo S, Imperi $F$, Vergnaude $G$, et al. Identification of variablenumber tandem-repeat (VNTR) sequences in Acinetobacter baumannii and interlaboratory validation of an optimized multiple-locus VNTR analysis typing scheme. J Clin Microbiol. 2011 Feb;49(2):539-48.

7 Van Belkum A, Kluytmans J, Van Leeuwen W, Bax R, Quint W, Peters E, et al. Multicenter evaluation of arbitrarily primed PCR for typing of Staphylococcus aureus strains. J Clin Microbiol. 1996 Jun;33(6): 1537-47. 
8 Keim P, Price LB, Klevytska AM, Smith KL, Shupp JM, Okinaka R, et al. Multiple-locus variable-number tandem repeat analysis reveals genetic relationships within Bacillus anthracis. J Bacteriol. 2000 May; 182(10):2928-36.

9 Denoeud F, Vergnaud G. Identification of polymorphic tandem repeats by direct comparison of genome sequence from different bacterial strains: a web-based resource. BMC Bioinformatics. 2004 Jan;5:4.

10 Zahner V, Cabral DA, Régua-Mangia AH, Rabinovitch L, Moreau G, Mclntosh D. Distribution of genes encoding putative virulence factors and fragment length polymorphisms in the vrrA gene among Brazilian isolates of Bacillus cereus and Bacillus thuringiensis. Appl Environ Microbiol. 2005 Dec;71(12):8107-14.

11 Liao JC, Li CC, Chiou CS. Use of a multilocus variable-number tandem repeat analysis method for molecular subtyping and phylogenetic analysis of Neisseria meningitides isolates. BMC Microbiol. 2006 May;6:44.

12 Turton JF, Matos J, Kaufmann ME, Pitt TL. Variable number tandem repeat loci providing discrimination within widespread genotypes of Acinetobacter baumannii. Eur J Clin Microbiol Infect Dis. 2009 May;28(5):499-507.

13 Carvalho KR. Estudo da diversidade genética, caracterização fenotípica e molecular de mecanismos de resistência a antimicrobianos e virulência em Acinetobacter baumannii isolados em hospitais do Rio de Janeiro [tese]. Rio de Janeiro (RJ): Fundação Oswaldo Cruz, Instituto Oswaldo Cruz; 2013.
14 Carvalho KR, Carvalho-Assef APD, Peirano G, Santos LCG, Pereira MJF, Asensi MD. Dissemination of multidrug-resistant Acinetobacter baumannii genotypes carrying bla ${ }_{\text {OXA-23 }}$ collected from hospitals in Rio de Janeiro, Brazil. Int J Antimicrob Agents. 2009 Jul;34(1):25-8.

15 TopJ,Schouls LM, Bonten MJ, Willems RJ. Multiple-locus variable-number tandem repeat analysis, a novel typing scheme to study the genetic relatedness and epidemiology of Enterococcus faecium isolates. J Clin Microbiol. 2004 Oct;42(10):4503-11.

16 Minandri F, D'Arezzo S, Antunes LC, Pourcel C, Principe $\mathrm{L}$, Petrosillo $\mathrm{N}$, et al. Evidence of diversity among epidemiologically related carbapenemase-producing Acinetobacter baumannii strains belonging to international clonal lineage II. J Clin Microbiol. 2012 Mar;50(3):590-7.

17 Hauck Y, Soler C, Jault P, Mérens A, Gérome P, Nab $C M$, et al. Diversity of Acinetobacter baumannii in four French military hospitals, as assessed by multiple locus variable number of tandem repeats analysis. PLoS One. 2012;7(9):e44597.

18 Hu Y, Li B, Jin D, Cui Z, Tao X, Zhang B, et al. Comparison of multiple-locus variable-number tandem-repeat analysis with pulsed-field gel electrophoresis typing of Acinetobacter baumannii in China. J Clin Microbiol. 2013 Apr;51 (4):1263-8.

Received / Recebido em / Recibido en: 2/10/2013 Accepted / Aceito em / Aceito en: 10/3/2014 